\title{
The Use of Cannabis for Headache Disorders
}

\author{
Bryson C. Lochte, Alexander Beletsky, Nebiyou K. Samuel, and Igor Grant ${ }^{*}$
}

\begin{abstract}
Headache disorders are common, debilitating, and, in many cases, inadequately managed by existing treatments. Although clinical trials of cannabis for neuropathic pain have shown promising results, there has been limited research on its use, specifically for headache disorders. This review considers historical prescription practices, summarizes the existing reports on the use of cannabis for headache, and examines the preclinical literature exploring the role of exogenous and endogenous cannabinoids to alter headache pathophysiology. Currently, there is not enough evidence from well-designed clinical trials to support the use of cannabis for headache, but there are sufficient anecdotal and preliminary results, as well as plausible neurobiological mechanisms, to warrant properly designed clinical trials. Such trials are needed to determine short- and long-term efficacy for specific headache types, compatibility with existing treatments, optimal administration practices, as well as potential risks.
\end{abstract}

Keywords: cannabis; headache; therapy

\section{Introduction}

Headache is a major public health concern, with enormous individual and societal costs (estimated at \$14.4 billion annually) due to decreased quality of life and disability. ${ }^{1}$ Each year, $\sim 47 \%$ of the population experience headache, including migraine (10\%), tension-type headache $(38 \%)$, and chronic daily headache $(3 \%) .^{2} \mathrm{~A}$ sexual dimorphism exists for headache disorders, with women 2-3 times more likely to experience migraine $^{3}$ and 1.25 times more likely to experience tension-type headache than men. ${ }^{4}$

The present review will focus largely on migraine, tension-type headache, trigeminal autonomic cephalalgias (specifically cluster headache), and medicationoveruse headache $(\mathrm{MOH})$. Migraine is classified as a $4-72 \mathrm{~h}$ headache that is typically unilateral, pulsating, of moderate-to-severe intensity, and associated with photophobia and phonophobia. ${ }^{5,6}$ Tension-type headache is classified as frequent, infrequent, or chronic, typically presenting with bilateral tightening pain of mild-to-moderate intensity and lasting minutes to days. ${ }^{6,7}$ Cluster headache is defined as severe unilateral pain in orbital, temporal, and/or supraorbital locations, lasting $15-180 \mathrm{~min}$ and typically occurring frequently and at regular intervals. ${ }^{6,8} \mathrm{MOH}$ is a chronic condition (occurs more than 15 days per month) that develops from frequent use of anti-headache medications. ${ }^{6,9}$

The pathophysiology of headache disorders is still under investigation. However, it is believed that migraine and cluster headaches are initiated in the brain in areas such as the hypothalamus, brainstem, or possibly cortex. ${ }^{6}$ Tension-type headaches can not only originate in the central nervous system but may also be triggered by myofascial tissue, often developing in response to stress. ${ }^{10}$ Regardless of origin, headaches usually involve overactivation of the trigeminovascular pathway, resulting in the release of vasoactive peptides, such as calcitonin gene-related peptide (CGRP) and substance $\mathrm{P}$, as well as vasoactive mediators such as nitrous oxide (NO), which can lead to further sensitization of

Department of Psychiatry, Center for Medicinal Cannabis Research, University of California, San Diego, La Jolla, California.

*Address correspondence to: Igor Grant, MD, Department of Psychiatry, Center for Medicinal Cannabis Research, University of California, San Diego, 9500 Gilman Drive, La Jolla, CA 92093-0603, E-mail: igrant@ucsd.edu

(C) Bryson C. Lochte et al. 2017; Published by Mary Ann Liebert, Inc. This Open Access article is distributed under the terms of the Creative Commons License (http://creativecommons.org/licenses/by/4.0), which permits unrestricted use, distribution, and reproduction in any medium, provided the original work is properly credited. 
nociceptive receptors in the head and neck. ${ }^{11}$ Serotoninergic signaling, parasympathetic efferents, inflammation, and increased intracranial pressure also play important roles in headache disorders. ${ }^{12,13}$

Treatment depends on the underlying headache condition; however, some popular options include NSAIDs for mild headaches and triptans, antidepressants, verapamil, or ergotamine for more severe or chronic headaches. ${ }^{14}$ These may be complemented by nonpharmacological interventions such as cognitivebehavioral therapy or relaxation training. ${ }^{15}$ Despite many treatment options, less than half of headache sufferers experience remission, and many continue to develop more severe or chronic headaches throughout their lifetime. ${ }^{16}$ Moreover, headache disorders are often underrecognized and undertreated. ${ }^{17}$ This current situation warrants an exploration of additional treatment options for headache disorders, with favorable side-effect profiles and efficacy in refractory patients.

One such option, cannabis, has been ignored in the United States for the past several decades but has an established history in the treatment of headaches. Assyrian manuscripts from the second millennium BCE recommended cannabis to "bind the temples," 18 and Ayurvedic preparations in the third and fourth centuries BCE were indicated for "diseases of the head" such as migraines. ${ }^{19}$ The prescription of cannabis was even recommended in ancient Greece, with Pedanius Dioscorides describing its use in his De Maternia Medica as a treatment for "pain of the ears." ${ }^{20}$ Other citations documenting the use of cannabis for headache disorders arise from the ninth century in the Al-Aqrabadhin Al-Saghir, the earliest known document of Arabic pharmacology. ${ }^{19}$ Further recommendations are found in Persian texts from the $10 \mathrm{th}^{21}$ and 17th centuries. $^{22}$ Prominent physicians of the Middle Ages, including John Parkinson ${ }^{23}$ and Nicholas Culpeper, ${ }^{24}$ also recommended the use of cannabis for headache.

The reintroduction of cannabis to the West in $1839^{25}$ began a century of its use as an effective treatment for headache disorders ${ }^{26}$ until its illegalization in $1937 .{ }^{27}$ Notable physicians who espoused the benefits of cannabis for headache disorders included John Russell Reynolds, the personal physician of Queen Victoria, ${ }^{28}$ American neurologist Silas Weir Mitchell, ${ }^{29}$ the president of the New York Neurological Society Edouard C. Seguin, ${ }^{19}$ William Gowers, a founding father of modern neurology, ${ }^{30}$ and Sir William Osler, often considered the father of modern medicine. ${ }^{31}$
When cannabis was deemed illegal by the U.S. government, its therapeutic use and research into its medical potential was largely discontinued. To this day, there are few clinical investigations of the use of cannabis for headache; however, the studies that have emerged demonstrate potential efficacy. In addition, numerous pre-clinical investigations ${ }^{18}$ have validated the role of endocannabinoids in preventing headache pathophysiology, which suggests a mechanistic role of cannabis in the treatment of these disorders. Although the cannabis plant comprises more than 100 cannabinoids, there has been little study of the individual effects of these cannabinoids on headache disorders; therefore, the present review will focus largely on the clinical potential of the cannabis plant as a whole.

The present review has four unique aims: (1) Highlight common historical trends in the use of cannabis in the treatment of headache to inform future clinical guidelines. (2) Briefly present the current clinical literature on this topic, with a focus on more recent publications that have not been discussed in past reviews. (3) Compile various preclinical studies into a prospective integrated model outlining the role of cannabinoids in the modulation of headache pathogenesis. (4) Outline several ${ }^{19,32-35}$ future directions that warrant exploration based on the limited, but promising findings on this topic.

\section{Materials and Methods}

The material presented was drawn from standard searches of the PubMed/National Library of Medicine database, influential sources of current medical literature, and past review articles. Search keywords included cannabis; cannabinoids; headache; migraine; cluster headache; medication-overuse headache; tetrahydrocannabinol; cannabidiol; clinical trial; placebo; and double blind. CliniacalTrials.gov was also queried for studies that have not yet been published. Individual articles were selected based on historical, clinical, or preclinical relevance to cannabinoids or cannabis as a treatment for headaches.

\section{Historical Use of Cannabis for Headache}

Historical reports, though not ideal forms of evidence, are important resources for understanding the potential use of cannabis in the treatment of headache disorders. Clinical publications between 1839 and 1937 provide valuable insights into the most effective practices, challenges, and benefits during an era when cannabis was commonly used to treat headache. 
Table 1. Historical Reports of the Use of Cannabis as a Treatment for Headache (19th and Early 20th Century)

\begin{tabular}{|c|c|c|c|c|}
\hline Usage & Administration & Sample & Result & Source \\
\hline Migraine & $\begin{array}{l}\text { A: } 0.03 \text { fluid ounce of alcohol } \\
\text { extract } 1 \mathrm{~h} \text { before pain onset }\end{array}$ & 4 Case studies & $\begin{array}{l}\text { Distinct termination of migraine. All patients } \\
\text { experienced improvement, some were cured. }\end{array}$ & Donovan $^{41}$ \\
\hline Migraine & $\begin{array}{l}\text { A: } 21.6 \mathrm{mg} \\
\text { P: } 21.6 \mathrm{mg} \text { 一three times daily }\end{array}$ & 2 Case studies & $\begin{array}{l}\text { Immediate relief and elimination of headache } \\
\text { for } 14 \text { months after treatment. } \\
\text { No lasting harm. }\end{array}$ & Reynolds $^{27}$ \\
\hline $\begin{array}{l}\text { Migraine/ } \\
\text { headache }\end{array}$ & $\begin{array}{l}\text { P: } 21.6 \mathrm{mg}, 1-2 \text { times per day } \\
\text { (can increase to } 43.2 \mathrm{mg} \text { ) }\end{array}$ & $\begin{array}{l}9 \text { Case studies } \\
\text { and clinical } \\
\text { experience }\end{array}$ & $\begin{array}{l}\text { Responses in majority of cases. Usually lasting } \\
\text { relief, sometimes curative. Palliative } \\
\text { during headache. }\end{array}$ & $\begin{array}{l}\text { Greene }^{35} ; \\
\text { Russo }^{18}\end{array}$ \\
\hline $\begin{array}{l}\text { Clavus hystericus } \\
\text { and migraine }\end{array}$ & P: $21.6 \mathrm{mg}$ to $43.2 \mathrm{mg}$ every night & Textbook & Palliation even in severe cases. & Waring $^{36}$ \\
\hline $\begin{array}{l}\text { Migraine or } \\
\text { sick headache }\end{array}$ & $\begin{array}{l}\text { P: Taken before each meal } \\
\text { (Women: } 21.6 \mathrm{mg} \text { increased to } \\
32.4 \text { after } 2-3 \text { weeks; Men: } 32.4 \\
\text { increased to } 48.6 \text { ) }\end{array}$ & $\begin{array}{l}\text { Clinical } \\
\quad \text { experience }\end{array}$ & $\begin{array}{l}\text { Majority of patients reported } \\
\text { migraine relief for months. }\end{array}$ & $\begin{array}{l}\text { Seguin (1878) } \\
\text { cited in } \\
\text { Russo }^{18}\end{array}$ \\
\hline $\begin{array}{l}\text { Migraine or } \\
\text { sick headache }\end{array}$ & $\begin{array}{l}\text { A: } 21.6-32.4 \mathrm{mg} \text { at beginning of attack. } \\
\text { P: } 21.6-32.4 \mathrm{mg}, 2-3 \text { times daily, } \\
\text { for weeks or months continuously. }\end{array}$ & $\begin{array}{l}\text { Clinical } \\
\quad \text { experience }\end{array}$ & $\begin{array}{l}\text { Found to be the most effective drug for } \\
\text { migraine. Can abort attacks in some cases. }\end{array}$ & Ringer $^{37}$ \\
\hline Migraine & $\begin{array}{l}\text { P: } 8.1-16.2 \mathrm{mg} \text { of solid extract } \\
\text { twice a day. } \\
\text { A: Take as needed }\end{array}$ & $\begin{array}{l}\text { Clinical } \\
\quad \text { experience }\end{array}$ & $\begin{array}{l}\text { Helpful prophylactically and abortively, even } \\
\text { in cases of migraine refractory to other } \\
\text { treatments. }\end{array}$ & Hare $^{40}$ \\
\hline $\begin{array}{l}\text { Chronic daily } \\
\text { headache }\end{array}$ & $\begin{array}{l}\text { P: } 21.6-32.4 \mathrm{mg} \text { (increasing if necessary), } \\
2-3 \text { times per day for weeks } \\
\text { to months. }\end{array}$ & 4 Case studies & Cured complaints in a majority of cases. & Mackenzie $^{38}$ \\
\hline Migraine & $\begin{array}{l}\text { P: } 16.2 \mathrm{mg} \text { twice a day continuously } \\
\text { A: Take } 16.2 \mathrm{mg} \text { during onset of attack }\end{array}$ & Short report & $\begin{array}{l}\text { Given immediately will stop attack, } \\
\text { given periodically will reduce severity } \\
\text { and frequency. }\end{array}$ & Suckling $^{39}$ \\
\hline
\end{tabular}

A summary of historical treatment practices using cannabis for migraines can be seen in Table 1. Historical sources indicate that cannabis was used as an effective prophylactic and abortive treatment for headache disorders. Although dosing varied among physicians, most prescribed alcohol extractions of the drug in the range of $1 / 4$ to $1 / 2$ grain $(16-32 \mathrm{mg}){ }^{28,32,36-40}$ This dose was likely chosen to minimize the effects of intoxication while also providing effective therapeutic relief. Other providers suggested that doses should be progressively increased until modest effects of intoxication were felt. ${ }^{19}$ For prophylactic treatment, these doses were usually administered two to three times daily for weeks or even months. ${ }^{28,32,36-38}$ Acute treatment often involved higher doses taken as needed and, in some cases, smoked cannabis was recommended. ${ }^{19,41-42}$

Early reports of cannabis for the treatment of headache appear to be largely positive, with many patients experiencing a decrease in the frequency and intensity of their headache episodes. In some cases, headache was cured entirely even after cannabis discontinuation. ${ }^{28,32,36-42}$ Furthermore, these early clinical reports praise the apparent safety of long-term cannabis use, as well as its added benefits of mollifying the nausea and anxiety that often accompany headaches. A common emphasis was placed on the importance of specific purity, preservation, and ad- ministration of the cannabis as well as patient adherence in the efficacy of treatment.

\section{Clinical Studies on Cannabis Use for Headache}

The schedule 1 classification of marijuana in 1970 has made rigorous clinical studies on the treatment efficacy of this substance difficult. Currently, there are no placebo-controlled clinical studies examining the use of cannabis for headache; nevertheless, there have been a number of other studies published that give insight into its therapeutic efficacy (Table 2). ${ }^{19,43-58}$ However, care should be taken when interpreting the findings from these studies. With one exception, ${ }^{53}$ these studies did not include a control group, and given that the placebo effect can be altered by the context of treatment, ${ }^{59}$ it is reasonable to expect a significant placebo response given the pre-existing public popularity and notoriety of cannabis. Moreover, selfreports and case studies may have a bias toward immediate improvement without awareness of possible dependence, rebound, or withdrawal responses, which are important concerns in headache treatment. ${ }^{60}$ In fact, studies show that headache can be induced in $23.2 \%$ patients undergoing cannabis withdrawal. ${ }^{61}$

Nabilone, a synthetic cannabinoid mimicking tetrahydrocannabinol (THC), has been shown to decrease analgesic intake while reducing $\mathrm{MOH}$ pain in a 
Table 2. Clinical Reports of the Use of Cannabis or Exogenous Cannabinoids as a Treatment for Headache

\begin{tabular}{|c|c|c|c|}
\hline Subject population & Type of study & Significant findings & Source \\
\hline 3 Chronic smokers & Case series & $\begin{array}{l}\text { Migraines after cannabis cessation. Remission } \\
\text { of headache with return to use in one patient. }\end{array}$ & El-Mallakh ${ }^{42}$ \\
\hline Patient with migraine & Case report & $\begin{array}{l}\text { Women found superior relief of migraine with } \\
\text { cannabis compared with beta-blockers, opiates, } \\
\text { and ergots. }\end{array}$ & $\begin{array}{l}\text { Petro (1997) } \\
\text { cited in Russo }{ }^{18}\end{array}$ \\
\hline Patient with migraine & Case report & $\begin{array}{l}18 \text { years of treatment failure with standard } \\
\text { pharmaceuticals, found success with smoked cannabis. }\end{array}$ & $\begin{array}{l}\text { Grinspoon } \\
\quad \text { and Bakalar }{ }^{45}\end{array}$ \\
\hline Patient with migraine & Case report & $\begin{array}{l}\text { Successful treatment with cannabis that did } \\
\text { not produce inebriation. }\end{array}$ & $\begin{array}{l}\text { Terwur (1997) } \\
\text { cited in Russo }\end{array}$ \\
\hline $\begin{array}{l}121 \text { Patients prescribed } \\
\text { cannabis for migraine }\end{array}$ & $\begin{array}{l}\text { Retrospective } \\
\text { study }\end{array}$ & $\begin{array}{l}\text { Migraine occurrences decreased from } 10.4 \text { to } \\
4.6 \text { per month; } 39.7 \% \text { had a positive effect, } 19.8 \% \text { had } \\
\text { decreased frequency, and } 11.6 \% \text { had aborted pain. }\end{array}$ & Rhyne et al. ${ }^{46}$ \\
\hline $\begin{array}{l}5 \text { Cases of chronic } \\
\text { migraine headache }\end{array}$ & Case series & $\begin{array}{l}\text { All cases successfully treated with dronabinol or } \\
\text { cannabis. In one case, cannabis improved response } \\
\text { more than dronabinol. In three cases, cannabis was } \\
\text { used to abort headache in the prodromal phase. }\end{array}$ & Mikuriya $^{48}$ \\
\hline $\begin{array}{l}1655 \text { Patients seeking physician } \\
\text { recommendation for } \\
\text { medical cannabis }\end{array}$ & Survey & $\begin{array}{l}40.8 \% \text { of applicants reported improvement of } \\
\text { headache symptoms with cannabis. }\end{array}$ & Nunberg et al. ${ }^{49}$ \\
\hline $\begin{array}{l}3 \text { Subjects with chronic } \\
\text { headaches }\end{array}$ & Case series & $\begin{array}{l}\text { Smoking cannabis caused relief similar or greater } \\
\text { than ergotamine and aspirin. }\end{array}$ & Noyes Jr. and Baram ${ }^{50}$ \\
\hline $\begin{array}{l}30 \text { Outpatients with medication- } \\
\text { overuse headache }\end{array}$ & $\begin{array}{l}\text { Clinical Trial } \\
\quad \text { (RDAC-Crossover) }\end{array}$ & $\begin{array}{l}\text { Nabilone was superior to ibuprofen in reducing } \\
\text { pain intensity, analgesic intake, and medication } \\
\text { dependence while improving quality of life. }\end{array}$ & Pini et al. ${ }^{52}$ \\
\hline $\begin{array}{l}\text { Patient with refractory } \\
\text { cluster headache }\end{array}$ & Case report & $\begin{array}{l}\text { Smoked cannabis or dronabinol at the beginning } \\
\text { of cluster headache provided complete immediate } \\
\text { headache relief. }\end{array}$ & Robbins et al. ${ }^{53}$ \\
\hline $\begin{array}{l}113 \text { Patients with chronic } \\
\text { cluster headache }\end{array}$ & Survey & $26 \%$ regularly used cannabis. Use as treatment unknown. & Donnet et al. ${ }^{54}$ \\
\hline $\begin{array}{l}139 \text { Patients with chronic } \\
\text { cluster headache }\end{array}$ & Survey & $\begin{array}{l}\text { Overall, } 45.3 \% \text { had used cannabis, and } 19.4 \% \text { had used } \\
\text { it to treat cluster headache; } 25.9 \% \text { found efficacy, } \\
\text { and the remainder found variable or negative effects. }\end{array}$ & Leroux et al. ${ }^{55}$ \\
\hline $\begin{array}{l}\text { Patient with pseudotumor } \\
\text { cerebri }\end{array}$ & Case report & $\begin{array}{l}\text { Complete resolution of headache with smoking } \\
\text { cannabis in }<5 \text { min without reoccurrence. }\end{array}$ & Evans and Ramadan ${ }^{56}$ \\
\hline $\begin{array}{l}112 \text { Patients with MS-associated } \\
\text { trigeminal neuralgia }\end{array}$ & Survey & $\begin{array}{l}\text { Overall, } 70 \% \text { found relief from trigeminal neuralgia, } \\
\text { and } 90 \% \text { found chronic pain relief. }\end{array}$ & Consroe et al. ${ }^{57}$ \\
\hline
\end{tabular}

MS, multiple sclerosis.

double-blind, placebo-controlled trial. ${ }^{53}$ In this study, 26 patients with treatment refractory $\mathrm{MOH}$ completed a course of either nabilone $(0.5 \mathrm{mg})$ or ibuprofen (400 mg) for 8 weeks, then after a week-long washout period, completed a second 8-week course of the previously excluded medication. Oral cannabinoid administration was chosen over an oromusocal THC spray, both because oral administration avoids the concentration peaks that can lead to euphoric effects and because chronic administration better overcomes individual differences in bioavailability. Although both substances showed improvement from baseline, nabilone was significantly more effective than ibuprofen in reducing pain intensity, analgesic intake, and medication dependence, as well as in improving quality of life. This study also examined the safety of nabilone as a treatment for headache and found that patients only experienced mild adverse effects that disappeared after discontinuation of the medication. The results of this study are significant, especially given that $\mathrm{MOH}$ is exacerbated by many pharmacological treatments. This study also highlights the potential value of cannabis in combination therapies, as a supplement to traditional treatments, or as a secondary treatment in refractory cases. Currently, a multicenter, double-blind, placebo-controlled study is being performed to examine the safety and efficacy of a dronabinol, or synthetic THC, metered dose inhaler for the treatment of migraine (clincaltrials.gov, NCT Identifier: NCT00123201). When published, this study could give valuable insights into the efficacy and risks of cannabinoids for the treatment of migraines.

Cannabis and cannabinoids have been studied clinically for other conditions, showing efficacy in the treatment of neuropathic/chronic pain, spasticity, and nausea. ${ }^{62-66}$ These three conditions are associated mechanistically and qualitatively with the experience of headache and, although the clinical literature for each of these conditions exceeds the scope of this review, it is plausible that their efficacy will carry over 
in the treatment of headache disorders as well. For example, the analgesic properties of cannabis seen in the treatment of neuropathic pain will likely apply to chronic headache, the antispasmodic properties seen in the treatment of multiple sclerosis could apply to muscle strain known to induce tension headaches, and the antiemetic properties seen in the treatment of chemotherapy-associated nausea might also palliate migraine-induced nausea.

Many individuals are currently using cannabis for the treatment of migraine and headache with positive results. In a survey of nine California clinics $(N=1746)$, physicians recorded headaches and migraines as a reason for approving a medical marijuana ID card in $2.7 \%$ of cases, and $40.7 \%$ patients selfreported that cannabis had therapeutic benefits for headaches and migraines. In another California survey of 7525 patients, $8.43 \%$ of patients reported that they were using medical cannabis to treat migraines. Another survey of 1430 patients found that $9 \%$ of patients were using medical cannabis to treat migraines (subdivided into $7.5 \%$ for classical migraines, $1 \%$ for cluster headaches, and $0.5 \%$ for others). Other studies have reported the use of cannabis for migraine or headache relief, with specific estimates including 5\% $(N=24,800)$ and $6.6 \%(N=128)$ for migraines and $3.6 \%(N=128)$ and $7.4 \%(N=217)$ for headache.

Other studies have looked specifically at the change in the occurrence of headache disorders with use of cannabis. ${ }^{52}$ One retrospective study described 121 patients who received cannabis for migraine treatment, among whom $85.1 \%$ of these patients reported a reduction in migraine frequency. ${ }^{47}$ The mean number of migraines at the initial visit was 10.4, falling to 4.6 at follow-up visits after cannabis treatment. Moreover, $11.6 \%$ of the patients found that, when smoked, cannabis could effectively arrest the generation of a migraine. These results indicate that cannabis may be an effective treatment option for certain migraine sufferers.

Reports from 139 cluster headache patients ${ }^{56}$ indicate that cannabis could have value in treating a portion $(25.9 \%)$ of these patients as well. However, cannabis was reported to provoke cluster headache attacks in some patients $(22.4 \%)$ as well. One possible explanation for this provoking effect is that cannabis is known to increase heart rate, increase blood pressure, and cause systemic vasodilation. ${ }^{67}$ Cluster headache sufferers seem to be highly sensitive to vasodilation of the carotid tree and increased oxygen demands, findings that are supported by evidence that alcohol is a re- liable trigger and supplemental oxygen is an effective abortive therapy. ${ }^{68}$ The increased oxygen demand and/or the vasodilation effects of cannabis could theoretically be responsible for this exacerbation in some cluster headache sufferers. Interestingly, cluster headaches appear to show improvement with treatment using hallucinogens such as d-lysergic acid amide (ergine or LSA), psilocybin, and lysergic acid diethylamide (LSD). ${ }^{33}$ As such, it is possible that the psychoactive properties of THC could play a role in the treatment of cluster headaches.

Case reports also give insights into the mechanisms behind the anti-headache action of cannabis. Smoking cannabis has been reported to relieve pain associated with pseudotumor cerebri, ${ }^{57}$ a condition that is characterized by an increase in the intracranial pressure of an uncertain etiology. This suggests that the therapeutic effect of cannabis in some headache conditions could be a result of reducing intracranial pressure. In fact, dexanabinol, a synthetic cannabinoid, has been found to relieve intracranial pressure and improve outcomes after traumatic brain injury. ${ }^{69}$

\section{Cannabinoids and Headache Pathophysiology}

The pathophysiological mechanisms of many headache disorders are not entirely understood. Nevertheless, preclinical data examining the effects of endocannabinoids on the neurological and vascular systems demonstrate the influence of endocannabinoids in modulating several major components of migraine pathogenesis (Table 3 and Fig. 1). ${ }^{35,70-85}$

\section{Underlying cause of headaches}

Various genetic factors can predispose individuals to migraines. For example, studies have shown that a decrease in expression of the $c n r l$ gene, which encodes the cannabinoid receptor type 1 (CB1) receptor, is associated with migraine and trigeminovascular activation. ${ }^{70}$ Women who experience migraine also have increased activities of fatty acid amide hydrolase (FAAH), an enzyme used to degrade the endocannabinoid anandamide (AEA), and the endocannabinoid membrane transporter (EMT), a membrane transporter for AEA, leading to an overall decrease in levels of endocannabinoids. ${ }^{73}$ This finding could partially explain the increased prevalence of migraines in women. An examination of cerebrospinal fluid shows that individuals who experience migraines have decreased levels of AEA and increased levels of CGRP and NO (normally inhibited by AEA). These findings support the 
Table 3. Studies on the Role of Cannabinoids in Headache Pathogenesis

\begin{tabular}{|c|c|c|}
\hline $\begin{array}{l}\text { Mechanistic } \\
\text { category }\end{array}$ & Significant findings & Source \\
\hline Systemic & $\begin{array}{l}\text { Variants in the } \mathrm{cnr} 1 \text { gene (encodes for the CB1 receptor) resulting in decreased expression } \\
\text { of CB1 associated with migraine and trigeminovascular activation. } \\
\text { Levels of AEA are decreased in the cerebrospinal fluid of individuals with chronic migraine, } \\
\text { whereas levels of CGRP and NO (inhibited by AEA) are increased. } \\
\text { Endocannabinoid deficiency theorized as a possible cause for migraine and other chronic } \\
\text { pain disorders, including chronic migraine and medication-overuse headache. } \\
\text { Female migraineurs have increased FAAH and EMT activities. }\end{array}$ & $\begin{array}{l}\text { Juhasz et al. }{ }^{75} \\
\text { Sarchielli et al. }{ }^{76} \\
\text { Cupini et al. }{ }^{77} \\
\text { Cupini et al. }{ }^{78}\end{array}$ \\
\hline Cortex & $\begin{array}{l}\text { CB1 agonists suppress glutamatergic neurotransmission by inhibiting NMDA receptors. } \\
\text { CB1 agonists suppress CSD. }\end{array}$ & $\begin{array}{l}\text { Hampson et al. }{ }^{79} \\
\text { Kazemi et al. }{ }^{80}\end{array}$ \\
\hline Vasculature & $\begin{array}{l}\text { AEA reduced nitroglycerin-induced neuronal activation in the nucleus trigeminalis caudalis. } \\
\text { AEA inhibits dural blood vessel dilation induced by CGRP, capsaicin, and NO (model of } \\
\text { trigeminovascular nociceptive response). AEA also prevented the release of NO } \\
\text { by CGRP in dural arteries. } \\
\text { Hyperalgesia induced by NO nearly eliminated in FAAH deletion or with FAAH inhibitor. } \\
\text { AEA activates TRPV1 on afferent trigeminal ganglion neurons, leading to CGRP release } \\
\text { and cranial vasodilation. } \\
\text { CBD is TRPV1 agonist. Could desensitize receptor and inhibit pathophysiological mechanism } \\
\text { of headache. }\end{array}$ & $\begin{array}{l}\text { Nozaki et al. } .^{83} \\
\text { Akerman et al. } .^{93} \\
\text { Bisogno et al. } .^{84}\end{array}$ \\
\hline Platelets & $\begin{array}{l}\text { Endocannabinoid levels reduced in platelets of patients with migraine. } \\
\text { Platelets of women with migraine showed increased activity of FAAH when compared } \\
\text { with men with migraine. } \\
\text { Cannabinoid compounds may stabilize and inhibit } 5 \mathrm{HT} \text { release from platelets during a migraine. }\end{array}$ & $\begin{array}{l}\text { Rossi et al. }{ }^{85} \\
\text { Cupini et al. } \\
\text { Volfe et al. }\end{array}$ \\
\hline Brainstem & $\begin{array}{l}\text { CB1 receptor activation in PAG and RVM leads to top-down modulation of pain. } \\
\text { AEA potentiates } 5 \text { HT1A and inhibits } 5 \text { HT2A receptors. } \\
\text { Endocannabinoids interact with serotonergic neurons in the brainstem dorsal raphe } \\
\text { to modulate pain mechanisms. } \\
\text { NO increases activity of FAAH, leading to increased breakdown of endocannabinoids } \\
\text { in the midbrain/PAG. } \\
\text { Elevation of endocannabinoid levels in the PAG modulates descending nociceptive pathways } \\
\text { via CB1 and TRPV1. } \\
\text { CB1 receptor activation in the vIPAG attenuated trigeminocervical complex activity. This effect } \\
\text { was inhibited by the addition of the CB1 receptor antagonist or the } 5 \mathrm{HT} 1 \mathrm{~B} / 1 \mathrm{D} \text { receptor antagonist. }\end{array}$ & $\begin{array}{l}\text { Kelly and } \\
\text { Chapman } \\
\text { Boger et al. } \\
\text { Haj-Dahmane } \\
\text { and Shen } \\
\text { Greco et al. } \\
\text { Maione et al. }{ }^{89} \\
\text { Akerman et al. }{ }^{90}\end{array}$ \\
\hline
\end{tabular}

AEA, anandamide; CB1, cannabinoid receptor type 1; CBD, cannabidiol; CGRP, calcitonin gene-related peptide; CSD, cortical spreading depression; EMT, endocannabinoid membrane transporter; FAAH, fatty acid amide hydrolase; NMDA, $N$-methyl-D-aspartate; NO, nitrous oxide; PAG, periaqueductal gray; RVM, rostral ventromedial medulla; vIPAG, ventrolateral PAG.

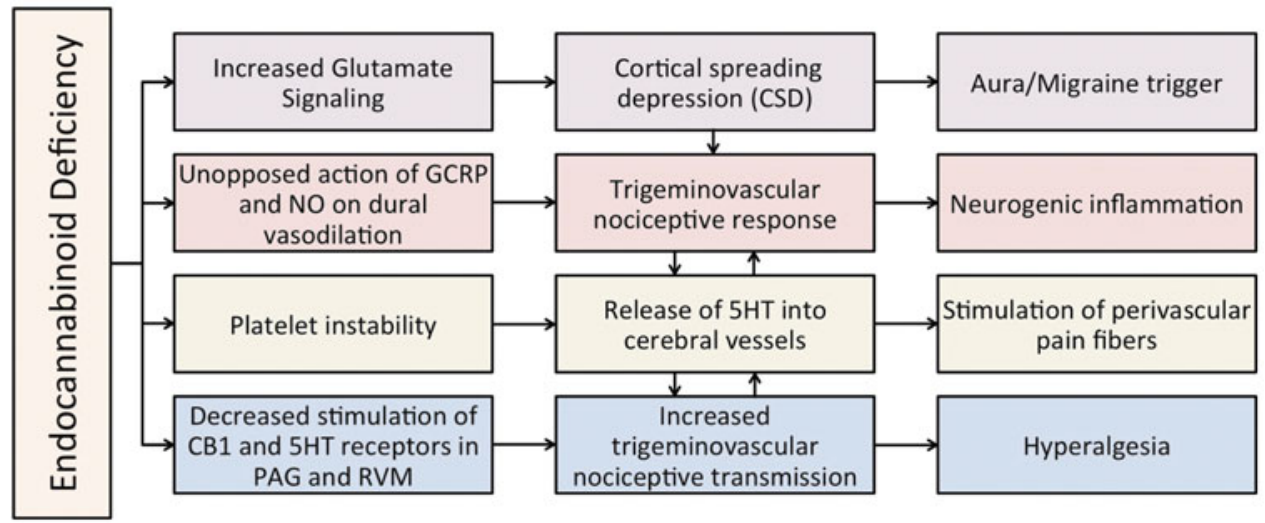

FIG. 1. Proposed model of the influence of cannabinoids on headache pathogenesis. Each branch corresponds to a mechanistic category listed in Table 3. Orange $=$ systemic; purple $=$ cortex; red $=$ vasculature; green $=$ platelets; blue $=$ brainstem . 
proposed theory that alterations in endocannabinoid function with reductions in endocannabinoids such as AEA may be one of the mechanisms underlying migraine. A feature of headache disorders is that they are highly associated with other comorbidities, including anxiety and mood disorders, allergies, chronic pain disorders, and epilepsy. ${ }^{86}$ The endocannabinoid deficiency hypothesis provides a possible mechanism underlying not only migraine but also diseases such as fibromyalgia and irritable bowel syndrome. ${ }^{72}$ Although the endocannabinoid deficiency hypothesis is still speculative and in need of further study, it suggests that exogenous stimulators of the endocannabinoid system, such as cannabis, could treat these diseases at their source. ${ }^{87}$

\section{Glutamate signaling}

One of the first subjective indicators of a migraine is the occurrence of an aura, a perceptual abnormality that often precedes a migraine attack. A wave of electrophysiological hyperactivity followed by inhibition, known as cortical spreading depression (CSD), is considered the neurobiological event underlying the migraine aura. CSD has been shown to be a result of excessive glutamate signaling, and one effect of endocannabinoids is the suppression of glutamate signaling via the inhibition of NMDA receptors. ${ }^{74}$ In fact, suppression of CSD has been achieved by THC and cannabinoid CB1 agonist activation of CB1 receptors in murine models. ${ }^{75}$ This suggests a use for cannabis in the prevention of the initial mechanisms triggering a migraine aura and the subsequent pain.

\section{Trigeminovascular activation}

Another component of most headache disorders is overactivation of the trigeminovascular system, the primary sensory nerve tree for the head. One of the most reliable triggers for migraine is NO. Studies have demonstrated the role of endocannabinoids in inhibiting NO. ${ }^{76}$ Moreover, AEA has been shown to inhibit dural vascular dilation caused by NO, CGRP, capsaicin, and electric stimulation. ${ }^{77}$ This effect may seem paradoxical, as cannabis is a known vasodilator and AEA acts through the vanilloid receptor TRPV1 to cause dilation of the cranial blood vessels. ${ }^{88}$ However, because cannabinoids such as THC bind preferentially with CB1 receptors over TRPV $1,{ }^{89}$ concentration could determine whether cannabinoids have a vasodilatory or vasoconstrictive effect. For example, at low concentrations, AEA inhibits neurogenic vasodilation, but at higher concentrations, AEA will begin binding with TRPV1 and induce vasodilation. ${ }^{88}$ This concentrationdependent activation of TRPV1 may underlie some of the paradoxical (e.g., anxiogenic, hyperalgesic) effects of THC seen at higher doses. Moreover, vasodilation is not necessarily pathogenic for headaches, and endocannabinoid-induced vasodilation could desensitize the vasculature to known headache progenitors, such as NO. Interestingly, NO appears to also exert nociceptive effects through FAAH, as deletion of an FAAH inhibitor or addition of an FAAH inhibitor prevents nociceptive reaction to $\mathrm{NO}^{78}$ One could postulate a possible feedback effect wherein $\mathrm{NO}$ and FAAH overpower endocannabinoids to illicit pain.

\section{Platelet stabilization}

The hematological properties within the dilated cranial blood vessels themselves may also play an important role in the pathophysiology of migraine. Endocannabinoid levels are reduced in the platelets of migraine patients, ${ }^{80}$ and women with migraine show increased FAAH and EMT activation in their platelets. ${ }^{73}$ Research has indicated that migraine might, in part, result from serotonin that is released from aggregating platelets, ${ }^{90}$ a theory that is supported by the efficacy of antiplatelet medications in some migraine sufferers. Cannabinoid compounds have been shown to stabilize platelets and prevent release of serotonin from platelets during a migraine. ${ }^{91}$

\section{Modulation of afferent nociceptive signals}

Endocannabinoids have a well-established role in the modulation of pain signals at the spinal level ${ }^{81}$ and contribute to the descending modulation of pain through brainstem nuclei. ${ }^{92}$ Endocannabinoids also inhibit trigeminovascular nociceptive processing with dural inputs. ${ }^{93}$ The activation of the trigeminovascular system leads to activation of cutaneous evoked afferent $\mathrm{A}$ and C-fibers. ${ }^{93}$ Endocannabinoids inhibit these signals via projections from the periaqueductal gray (PAG) and rostral ventral medulla. ${ }^{94-96} \mathrm{CB} 1$ receptor activation in the ventrolateral PAG has also been shown to modulate nociceptive trigeminovascular transmission in the trigeminocervical complex via activation of $5 \mathrm{HT} 1 \mathrm{~B} / 1 \mathrm{D}$ receptors. ${ }^{85}$ Endocannabinoids also influence serotonergic neurons within the brainstem dorsal raphe to modulate pain. ${ }^{83}$

Triptans, one of the most effective abortive treatments for migraine and cluster headaches, are believed to act through agonist effects on $5 \mathrm{HT} 1 \mathrm{~B} / 1 \mathrm{D}$ receptors on the nerve endings in cranial blood vessels, ${ }^{97}$ as 
well as brainstem regions, including the $\mathrm{PAG},{ }^{85}$ resulting in decreased release of pro-inflammatory neuropeptides such as substance P and CGRP and attenuation of dural nociceptive responses. Since $5 \mathrm{HT} 1 \mathrm{~B} / 1 \mathrm{D}$ antagonists can inhibit the $\mathrm{CB} 1$ modulation of nociceptive trigeminovascualr signals, triptans may induce their antimigraine effects by activating endocannabinoidcontaining neurons in the PAG. ${ }^{85}$

\section{Discussion}

Headache disorders are common, painful, and disabling; moreover, treatment for these disorders is inadequate for many sufferers. Before cannabis was made illegal, many prominent physicians praised its use in the treatment of headache disorders. Reports from this period emphasize the administration of consistent and uniform doses and the titration of doses to minimize intoxication. For prophylactic treatment, cannabis was typically given orally two to three times per day, for weeks or even months, ${ }^{28,32,36-38}$ and for abortive treatment, cannabis was given at higher oral doses or smoked. ${ }^{19,41,42}$ If cannabis is to be reconsidered as a treatment for headache, considering this historical perspective could improve the efficacy of treatments and help inform future research.

Although there have not been any clinical trials of cannabis as a treatment for headache to date, reports indicate that cannabis is commonly used by patients to self-medicate for headache disorders. A retrospective analysis has shown a significant impact of cannabis in treating migraine ${ }^{47}$ and a clinical trial of a synthetic cannabinoid showed efficacy for $\mathrm{MOH}^{53}$ but properly designed placebo-controlled trials are needed to determine the true efficacy and complications of cannabis treatment for headache disorders.

Preclinical studies examining the role of the endocannabinoid system in migraine pathogenesis also suggest a potential therapeutic value for cannabis in the treatment of headache. It has been postulated that a general deficiency in endocannabinoid tone could underlie headache disorders. ${ }^{72}$ Cannabis also shows potential to interrupt specific stages in the pathogenesis of headaches, including glutamate signaling leading to $\mathrm{CSD},{ }^{75}$ cranial blood vessel dilation caused by $\mathrm{NO}$ and CGRP, ${ }^{77}$ serotonin release from platelets, ${ }^{91}$ and afferent trigeminovascular nociceptive inputs. ${ }^{85}$ Although these studies have suggested an interesting relationship between endocannabinoids and some pathogenic processes of headache disorders, the mechanistic role of cannabis in preventing headache disorders remains speculative.
The studies presented in this review indicate the importance of further well-designed clinical trials of the efficacy of cannabis in the treatment of headache disorders. Because there are still many obstacles present in constructing double-blind placebo-controlled clinical trials of cannabis, the following list outlines various other potential future investigations and recommendations based on the findings presented in this review.

1. The development of dosing and treatment guidelines for the use of cannabis in the treatment of headache disorders. Physicians should consider discussing dosing strategies when recommending cannabis as headache treatment, with the aim of maximizing efficacy and minimizing harm. A focus on dose consistency through the use of oral cannabinoids or metered-dose inhalers could benefit future clinical trials by allowing for easier blinding and placebo control. Moreover, the use of oral cannabinoids could have unique benefits in the prophylactic treatment of headache, because it could avoid concentration peaks and individual differences in bioavailability.

2. Investigation of the anti-headache effect of cannabidiol (CBD). This review found no available information on the use of $\mathrm{CBD}$ as a treatment for headache. Nevertheless, CBD has shown efficacy for headache-related conditions (i.e., anxiety), ${ }^{98}$ has demonstrated an analgesic role associated with TRPV1 receptors, ${ }^{99}$ and can serve as a 5HT1a receptor agonist. ${ }^{100}$

3. Identification of variables that could predict treatment receptivity in headache patients. This could include stratification of headache disorders or patients based on sex, genetics, metabolic function, or neuronal biomarkers.

4. Investigation of the long-term risks of cannabis treatment for headaches. This should aim at quantifying any side effects, withdrawal symptoms, dependence, refractory headaches, or negative outcomes from cannabis treatment for headaches.

5. Evaluation of other anti-headache drugs that target the endocannabinoid system. Preclinical data suggest the possible use of FAAH or EMT inhibitors, which might have unique efficacy in female migraineurs.

6. Evaluation of cannabis in combination treatment (with analgesic or other anti-headache medications) or as a second-line treatment in patients who are refractory to traditional medications. 


\section{Conclusion}

The present review examines the historical guidelines for cannabis treatment of headache, available clinical data on the use of cannabis for headache, and preclinical literature on the role of the endocannabinoid system in headache pathophysiology. From this examination, various methodological recommendations are made for future studies and potentially novel treatment practices are considered. Although placebocontrolled clinical trials are still needed to appropriately determine efficacy, it appears likely that cannabis will emerge as a potential treatment for some headache sufferers.

\section{Acknowledgment}

This work was supported by the Center for Medicinal Cannabis Research (CMCR) at the University of California, San Diego.

\section{Author Disclosure Statement}

No competing financial interests exist.

\section{References}

1. Hu XH, Markson LE, Lipton RB, et al. Burden of migraine in the United States: disability and economic costs. Arch Intern Med. 1999;159: 813-818.

2. Stovner L, Hagen K, Jensen R, et al. The global burden of headache: a documentation of headache prevalence and disability worldwide. Cephalalgia. 2007;27:193-210.

3. Bille B. Migraine and tension-type headache in children and adolescents. Cephalalgia. 1996;16:80.

4. Rasmussen BK, Jensen $\mathrm{R}$, Schroll $\mathrm{M}$, et al. Epidemiology of headache in a general population-a prevalence study. J Clin Epidemiol. 1991:44:1147-1157.

5. Hansen JM, Levy D. Pathophysiology of migraine: current status and future directions. In: Pathophysiology of headaches. Headache (Ashina M, Geppetti P, eds.). Springer International Publishing: Switzerland, 2015, pp. 217-234.

6. Olesen J. The International Classification of Headache Disorders, 3rd edition. Cephalagia. 2013;33:629-808

7. Leone M, Proietti Cecchini A. Advances in the understanding of cluster headache. Expert Rev Neurother. 2017;17:165-172.

8. Munksgaard SB, Porreca F. Pathophysiology of medication overuse headache: current status and future directions. In: Pathophysiology of headaches. Headache (Ashina M, Geppetti $\mathrm{P}$, eds.). Springer International Publishing: Switzerland, 2015, pp. 259-272.

9. Waldie KE, Buckley J, Bull PN. Tension-type headache: A life-course review. Headache Pain Manag. 2016;1:1-9.

10. Goadsby PJ, Edvinsson L, Ekman R. Vasoactive peptide release in the extracerebral circulation of humans during migraine headache. Ann Neurol. 1990;28:183-187.

11. Friedman DI, Rausch EA. Headache diagnoses in patients with treated idiopathic intracranial hypertension. Neurology. 2002;58: 1551-1553.

12. Silberstein SD. Migraine pathophysiology and its clinical implications. Cephalalgia. 2004;24(Suppl 2):2-7.

13. Harrison TR. Harrison's principles of internal medicine. McGraw-Hill Professional: New York, vol. 53, 2013.

14. Rains JC, Penzien DB, McCrory DC, et al. Behavioral headache treatment: history, review of the empirical literature, and methodological critique. Headache. 2005;45(Suppl. 2):S92-S109.
15. Lyngberg AC, Rasmussen BK, Jørgensen $\mathrm{T}$, et al. Prognosis of migraine and tension-type headache: a population-based follow-up study. Neurology. 2005;65:580-585.

16. Jensen $\mathrm{R}$, Bendtsen L. Tension-type headache. In: Case-based diagnosis and management of headache disorders. Headache (Siva A, Lampl C, eds.). Springer International Publishing, 2015, pp. 147-155.

17. Thompson RC. The Assyrian herbal. Luzac and co.: London, 1924

18. Russo E. Hemp for headache: an in-depth historical and scientific review of cannabis in migraine treatment. J Cannabis Ther. 2001;1:21-92.

19. Gunther R, Goodyer J. The Greek herbal of Dioscorides: illustrated by a Byzantine, AD 512. Hafner Publishing Company: New York, 1968.

20. Lewis B, Menage VL, Pellat C, et al. Encyclopedia of Islam (New Edition), vol. III, EJ Brill (Leiden) \& Luzac \& Co.: London, 1971.

21. Dymock W. The vegetable Materia Medica of Western India. Education Society's Press: London, 1885

22. Parkinson J, Cotes T. Theatrum Botanicvm: the theater of plants. Or, an Herball of a large extent. London: Printed by Tho. Cotes, 1640.

23. Culpeper N. Culpeper's complete Herbal: consisting of a comprehensive description of nearly all herbs with their medicinal properties and directions for compounding. W. Foulsham Co. Ltd., London, 1984, xii, 430

24. O'Shaughnessy WB. On the preparations of the Indian Hemp, or Gunjah: Cannabis indica their effects on the animal system in health, and their utility in the treatment of tetanus and other convulsive diseases. Prov Med J Retrosp Med Sci. 1843;5:363.

25. Russo E. Cannabis for migraine treatment: the once and future prescription? An historical and scientific review. Pain. 1998;76:3-8.

26. Baum D. Smoke and mirrors: the war on drugs and the politics of failure. Little, Brown: Boston, 1996

27. Reynolds JR. On some of the therapeutical uses of Indian hemp. Arch Med. 1868;2:154-160

28. Mitchell S. Headaches, from heat-stroke, from fevers, after meningitis, from over use of brain, from eye strain. Headache J Head Face Pain. 1963;3:70-76.

29. Gowers WR. A manual of diseases of the nervous system (American edition). Blakiston: Philadelphia, 1888.

30. Osler W. The principles and practice of medicine. Appleton: New York 1909.

31. Greco R, Gasperi V, Maccarrone M, et al. The endocannabinoid system and migraine. Exp Neurol. 2010;224:85-91.

32. McGeeney BE. Cannabinoids and hallucinogens for headache. Headache. 2013;53:447-458.

33. Baron EP. Comprehensive review of medicinal marijuana, cannabinoids, and therapeutic implications in medicine and headache: what a long strange trip it's been. Headache. 2015;55:885-916.

34. Greco R, Gasperi V, Sandrini G, et al. Alterations of the endocannabinoid system in an animal model of migraine: evaluation in cerebral areas of rat. Cephalalgia. 2010;30:296-302.

35. Greene R. Cannabis indica in the treatment of migraine. Practitioner. 1872;41:267-270.

36. Waring EJ. Practical therapeutics. Lindsay \& Blakiston: Philadelphia, 1874

37. Ringer S. A Handbook of Therapeutics. H.K. Lewis: London, 1886

38. Mackenzie $S$. Remarks on the value of Indian hemp in the treatment of a certain type of headache. Br Med J. 1887;1:97.

39. Suckling CW. On the therapeutic value of Indian hemp. Br Med J. 1891;2:11-12.

40. Hare HA. Clinical and physiological notes on the action of Cannabis indica. Ther Gaz. 1887;11:225-228.

41. Donovan M. On the physical and medicinal qualities of Indian hemp (Cannabis indica); with observations on the best mode of administration, and cases illustrative of its powers. Dublin J Med Sci. 1845;26:368-461.

42. El-Mallakh RS. Marijuana and migraine. Headache. 1987;27:442-443.

43. El-Mallakh RS. Migraine headaches and drug abuse. South Med J. 1989;82:805.

44. Gieringer D. Experience in California. Cannabis Cannabinoids: Pharmacology, Toxicology, and Therapeutic Potential. Haworth Press: New York 2002, pp. 143-152.

45. Grinspoon L, Bakalar JB. Marihuana, the forbidden medicine. Yale University Press: New Haven, 1997.

46. Rhyne DN, Anderson SL, Gedde M, et al. Effects of medical marijuana on migraine headache frequency in an adult population. Pharmacotherapy. 2016;36:505-510. 
47. Osborn LA, Lauritsen KJ, Cross N, et al. Self-Medication of Somatic and Psychiatric Conditions Using Botanical Marijuana. J Psychoactive Drugs. 2015;47:345-350.

48. Mikuriya TH. Chronic migraine headache: five cases successfully treated with marinol and/or illiciit cannabis. Schaffer Library: Berkeley, CA, 1991

49. Nunberg $\mathrm{H}$, Kilmer $B$, Pacula RL, et al. An analysis of applicants presenting to a medical marijuana specialty practice in California. J Drug Policy Anal. 2011;4:1

50. Noyes Jr. R, Baram DA. Cannabis analgesia. Compr Psychiatry. 1974;15:531-535.

51. Schnelle M, Grotenhermen F, Reif $M$, et al. Results of a standardized survey on the medical use of cannabis products in the German-speaking area. Forsch Komplementarmed. 1999;6(Suppl 3):28-36.

52. Pini LA, Guerzoni S, Cainazzo MM, et al. Nabilone for the treatment of medication overuse headache: results of a preliminary doubleblind, active-controlled, randomized trial. J Headache Pain. 2012;13: 677-684.

53. Robbins MS, Tarshish S, Solomon S, et al. Cluster attacks responsive to recreational cannabis and dronabinol. Headache. 2009;49:914-916.

54. Donnet A, Lanteri-Minet M, Guegan-Massardier E, et al. Chronic cluster headache: a French clinical descriptive study. J Neurol Neurosurg Psychiatry. 2007;78:1354-1358.

55. Leroux E, Taifas I, Valade D, et al. Use of cannabis among 139 cluster headache sufferers. Cephalalgia. 2013;33:208-213.

56. Evans RW, Ramadan NM. Are cannabis-based chemicals helpful in headache? Headache. 2004;44:726-727.

57. Consroe P, Musty R, Rein J, et al. The perceived effects of smoked cannabis on patients with multiple sclerosis. Eur Neurol. 1997;38: 44-48.

58. Price DD, Finniss DG, Benedetti F. A comprehensive review of the placebo effect: recent advances and current thought. Annu Rev Psychol. 2008;59:565-590.

59. Lipton RB, Silberstein SD, Saper JR, et al. Why headache treatment fails Neurology. 2003;60:1064-1070.

60. Levin $\mathrm{KH}$, Copersino ML, Heishman SJ, et al. Cannabis withdrawal symptoms in non-treatment-seeking adult cannabis smokers. Drug Alcohol Depend. 2010;111:120-127.

61. Karschner EL, Darwin WD, McMahon RP, et al. Subjective and physiological effects after controlled sativex and oral THC administration. Clin Pharmacol Ther. 2011;89:400-407.

62. Williamson EM, Evans FJ. Cannabinoids in clinical practice. Drugs. 2000;60:1303-1314.

63. Andreae MH, Carter GM, Shaparin N, et al. Inhaled cannabis for chronic neuropathic pain: a meta-analysis of individual patient data. J Pain. 2015;16:1221-1232.

64. Hill KP. Medical marijuana for treatment of chronic pain and other medical and psychiatric problems: a clinical review. JAMA. 2015;313:2474-2483.

65. Koppel BS, Brust JCM, Fife T, et al. Systematic review: efficacy and safety of medical marijuana in selected neurologic disorders: report of the Guideline Development Subcommittee of the American Academy of Neurology. Neurology. 2014;82:1556-1563.

66. Tramèr MR, Carroll D, Campbell FA, et al. Cannabinoids for control of chemotherapy induced nausea and vomiting: quantitative systematic review. BMJ. 2001;323:16-21.

67. Grant I, Atkinson JH, Gouaux B, et al. Medical marijuana: clearing away the smoke. Open Neurol J. 2012;6:18-25.

68. Reinarman $\mathrm{C}$, Nunberg $\mathrm{H}$, Lanthier $\mathrm{F}$, et al. Who are medical marijuana patients? Population characteristics from nine California assessment clinics. J Psychoactive Drugs. 2011;43:128-135.

69. Ryan-Ibarra $S$, Induni $M$, Ewing D. Prevalence of medical marijuana use in California, 2012. Drug Alcohol Rev. 2015;34:141-146.

70. Mikuriya T, Hergenrather J, Denney PA, et al. Medical marijuana in California, 1996-2006. O'Shaughnessy's: The Journal of Cannabis in Clinica Practice. Winter/Spring 2007.

71. Bonn-Miller MO, Boden MT, Bucossi MM, et al. Self-reported cannabis use characteristics, patterns and helpfulness among medical cannabis users. Am J Drug Alcohol Abuse. 2014;40:23-30.

72. Kalant $H$. Adverse effects of cannabis on health: an update of the literature since 1996. Prog Neuropsychopharmacology Biol Psychiatry. 2004;28:849-863.
73. Fogan L. Treatment of cluster headache. A double-blind comparison of oxygen $v$ air inhalation. Arch Neurol. 1985;42:362-363.

74. Knoller N, Levi L, Shoshan l, et al. Dexanabinol (HU-211) in the treatment of severe closed head injury: a randomized, placebo-controlled, phase II clinical trial. Crit Care Med. 2002;30:548-554.

75. Juhasz G, Lazary J, Chase D, et al. Variations in the cannabinoid receptor 1 gene predispose to migraine. Neurosci Lett. 2009;461: 116-120.

76. Sarchielli P, Pini LA, Coppola F, et al. Endocannabinoids in chronic migraine: CSF findings suggest a system failure. Neuropsychopharmacology. 2007;32:1384-1390.

77. Cupini LM, Costa C, Sarchielli P, et al. Degradation of endocannabinoids in chronic migraine and medication overuse headache. Neurobiol Dis. 2008;30:186-189.

78. Cupini LM, Bari M, Battista N, et al. Biochemical changes in endocannabinoid system are expressed in platelets of female but not male migraineurs. Cephalalgia. 2006;26:277-281.

79. Hampson AJ, Bornheim LM, Scanziani M, et al. Dual effects of anandamide on NMDA receptor-mediated responses and neurotransmission. J Neurochem. 1998;70:671-676.

80. Kazemi H, Rahgozar M, Speckmann E-J, et al. Effect of cannabinoid receptor activation on spreading depression. Iran J Basic Med Sci. 2012;15:926-936.

81. Greco R, Mangione AS, Sandrini G, et al. Effects of anandamide in migraine: data from an animal model. J Headache Pain. 2011;12: 177-183.

82. Akerman S, Kaube H, Goadsby PJ. Anandamide is able to inhibit trigeminal neurons using an in vivo model of trigeminovascular-mediated nociception. J Pharmacol Exp Ther. 2004;309:56-63.

83. Nozaki C, Markert A, Zimmer A. Inhibition of FAAH reduces nitroglycerininduced migraine-like pain and trigeminal neuronal hyperactivity in mice. Eur Neuropsychopharmacol. 2015;25:1388-1396.

84. Bisogno $T$, Hanus $L$, De Petrocellis $L$, et al. Molecular targets for cannabidiol and its synthetic analogues: effect on vanilloid VR1 receptors and on the cellular uptake and enzymatic hydrolysis of anandamide. $\mathrm{Br} \mathrm{J}$ Pharmacol. 2001;134:845-852.

85. Rossi C, Pini LA, Cupini ML, et al. Endocannabinoids in platelets of chronic migraine patients and medication-overuse headache patients: relation with serotonin levels. Eur J Clin Pharmacol. 2008; 64:1-8.

86. Kelly S, Chapman V. Selective cannabinoid CB1 receptor activation inhibits spinal nociceptive transmission in vivo. J Neurophysiol. 2001;86:3061-3064.

87. Boger DL, Patterson JE, Jin Q. Structural requirements for $5-\mathrm{HT} 2 \mathrm{~A}$ and 5HT1A serotonin receptor potentiation by the biologically active lipid oleamide. Proc Natl Acad Sci U S A. 1998;95:4102-4107.

88. Haj-Dahmane S, Shen R-Y. Endocannabinoids suppress excitatory synaptic transmission to dorsal raphe serotonin neurons through the activation of presynaptic CB1 receptors. J Pharmacol Exp Ther. 2009;331:186-196.

89. Maione S, Bisogno T, de Novellis V, et al. Elevation of endocannabinoid levels in the ventrolateral periaqueductal grey through inhibition of fatty acid amide hydrolase affects descending nociceptive pathways via both cannabinoid receptor type 1 and transient receptor potential vanilloid type-1 receptors. J Pharmacol Exp Ther. 2006;316: 969-982.

90. Akerman S, Holland PR, Lasalandra MP, et al. Endocannabinoids in the brainstem modulate dural trigeminovascular nociceptive traffic via $C B$ and "triptan" receptors: implications in migraine. J Neurosci. 2013;33:14869-14877.

91. Antonaci F, Nappi G, Galli F, et al. Migraine and psychiatric comorbidity: a review of clinical findings. J Headache Pain. 2011;12:115-125.

92. Russo EB. Clinical endocannabinoid deficiency reconsidered: current research supports the theory in migraine, fibromyalgia, irritable bowel, and other treatment-resistant syndromes. Cannabis Cannabinoid Res. 2016;1:154-165.

93. Akerman S, Kaube $\mathrm{H}$, Goadsby PJ. Anandamide acts as a vasodilator of dural blood vessels in vivo by activating TRPV1 receptors. Br J Pharmacol. 2004;142:1354-1360.

94. Tóth A, Blumberg PM, Boczán J. Anandamide and the vanilloid receptor (TRPV1). Vitam Horm. 2009;81:389-419. 
95. Borgdorff $P$, Tangelder GJ. Migraine: possible role of shear-induced platelet aggregation with serotonin release. Headache. 2012;52:12981318.

96. Volfe Z, Dvilansky A, Nathan I. Cannabinoids block release of serotonin from platelets induced by plasma from migraine patients. Int J Clin Pharmacol Res. 1985;5:243-246.

97. De Novellis V, Mariani L, Palazzo E, et al. Periaqueductal grey CB1 cannabinoid and metabotropic glutamate subtype 5 receptors modulate changes in rostral ventromedial medulla neuronal activities induced by subcutaneous formalin in the rat. Neuroscience. 2005; 134:269-281.

98. Akerman S, Holland PR, Goadsby PJ. Cannabinoid (CB1) Receptor activation inhibits trigeminovascular neurons. J Pharmacol Exp Ther. 2007;320:64-71.

99. Knight YE, Goadsby PJ. The periaqueductal grey matter modulates trigeminovascular input: a role in migraine? Neuroscience. 2001;106: 793-800.

100. Knight YE, Bartsch T, Kaube H, et al. P/Q-type calcium-channel blockade in the periaqueductal gray facilitates trigeminal nociception: a functional genetic link for migraine? J Neurosci. 2002;22:RC213.

Cite this article as: Lochte BC, Beletsky A, Samuel NK, Grant I (2017)

The use of cannabis for headache disorders, Cannabis and

Cannabinoid Research 2:1, 61-71, DOI: 10.1089/can.2016.0033.

\section{Abbreviations Used}

$5 \mathrm{HT}=$ serotonin

$5 \mathrm{HT} 1 \mathrm{~A}=5$-hydroxytryptamine receptor $1 \mathrm{~A}$

$5 \mathrm{HT} 1 \mathrm{~B} / 1 \mathrm{D}=5$-hydroxytryptamine receptor $1 \mathrm{~B} / 1 \mathrm{D}$

$5 \mathrm{HT} 2 \mathrm{~A}=5$-hydroxytryptamine receptor $2 \mathrm{~A}$

$A=$ abortive

$\mathrm{AEA}=$ anandamide

$\mathrm{BCE}=$ Before Common Era

$\mathrm{CB} 1=$ cannabinoid receptor type 1

$\mathrm{CBD}=$ cannabidiol

CGRP $=$ calcitonin gene-related peptide

$\mathrm{CSD}=$ cortical spreading depression

$\mathrm{EMT}=$ endocannabinoid membrane transporter

$\mathrm{FAAH}=$ fatty acid amide hydrolase

$\mathrm{MOH}=$ medication-overuse headache

$\mathrm{MS}=$ multiple sclerosis

$\mathrm{NMDA}=\mathrm{N}$-methyl-D-aspartate

$\mathrm{NO}=$ nitrous oxide

NSAIDs $=$ nonsteroidal anti-inflammatory drugs

$\mathrm{P}=$ prophylactic

$P A G=$ periaqueductal gray

$\mathrm{RVM}=$ rostral ventromedial medulla

$\mathrm{THC}=$ tetrahydrocannabinol

TRPV1 $=$ transient receptor potential cation channel subfamily $\mathrm{V}$ member 1

vIPAG $=$ ventrolateral PAG

\section{Publish in Cannabis and Cannabinoid Research}

Cannabis and

Cannabinoid

Research
- Immediate, unrestricted online access

- Rigorous peer review

- Compliance with open access mandates

- Authors retain copyright

- Highly indexed

- Targeted email marketing

liebertpub.com/can 